\title{
ANALISIS PENGARUH PENDAPATAN PAJAK DAN RETRIBUSI TERHADAP BELANJA LANGSUNG DAN DAMPAKNYA PADA PERTUMBUHAN EKONOMI KOTA BITUNG 2005-2014
}

\author{
Debora Christian Wola ${ }^{1}$, David .P.E Saerang ${ }^{2}$, Een N. Walewangko ${ }^{3}$ \\ Fakultas Ekonomi dan Bisnis, Magister Ilmu Ekonomi \\ Universitas Sam Ratulangi, Manado
}

\section{ABSTRAK}

Otonomi daerah sejatinya merupakan pelimpahan wewenang dari sentralisasi ke desentralisasi, artinya kewenangan dari pusat sudah dilimpahkan ke daerah begitu juga dengan pengelolaan anggaran rumah tangganya sendiri.

Kemandirian ekonomi sebuah daerah juga dinilai dari tingkat Pendapatan Asli Daerah (PAD) yang dimiliki dibandingkan dengan dana transfer dari pemerintah pusat. Sumber-sumber PAD terbesar datang dari pajak, retribusi dan PAD lain yang sah. Dalam penelitian ini digunakan metode Ordinary Least Square (OLS) untuk mengetahui seberapa besar sumber-sumber PAD yakni pendapatan pajak, pendapatan retribusi mempengaruhi belanja pembangunan/ belanja langsung kota Bitung.

Dalam penelitian didapatkan hasil bahwa, pajak dan retribusi pengaruhnya secara partial terhadap belanja langsung masih amat kecil, hal yang hampir sama juga terjadi pada tingkat pengaruh secara simultan walaupun sedikit mengalami peningkatan namun tidak berpengaruh secara signifikan. Sedangkan untuk pengaruh alokasi belanja langsung terhadap pertumbuhan ekonomi amat signifikan baik secara partial maupun secara simultan.

Kata kunci : Pendapatan asli daerah, Pendapatan Pajak, Retribusi, Belanja Langsung, Pertumbuhan Ekonomi.

\section{ABSTRACT}

Regional autonomy is actually the delegation of authority from centralization to decentralization, meaning that the authority of the center has been delegated to the regions as well as the management of their own household budget.

Economic independence of a region are also assessed on the level of revenue (PAD) owned compared to the transfer of funds from the central government. The PAD sources come from taxes, fees and other legitimate PAD. In this study used Ordinary Least Square (OLS) to determine how much revenue sources namely income tax, income levy affects development expenditure / direct expenditure Bitung town.

In the study showed that, taxes and charges are partial influence on direct spending is still very small, almost the same thing happened at the level of influence simultaneously, although slightly increased, but not significantly. As for the effect of the allocation of direct spending on economic growth is very significant for both partially and simultaneously.

Keywords: Local Own-Source Revenue, income taxes, levy, direct expenditure, economic growth.

\section{Latar BelakangMasalah}

Pembangunan Sektor Publik dan transparansi keuangan publik menjadi fenomena global saat ini termasuk di Indonesia. Akuntabilitas serta transparansi dalam pengelolaaan keuangan Negara bahkan daerah menjadi hal yang krusial dewasa ini. Akuntabilitas publik adalah pemberian informasi dan pengungkapan seluruh aktivitas dan kerja financial pemerintah daerah kepada pihak-pihak yang berkepentingan (Mardiasmo, 2002). Dengan keterbukaan yang dilakukan banyak mata yang sebelumnya tidak terlalu perduli dan mengerti keuangan di sector publik mulai memberi perhatian lebih mulai dari para pengamat, pemegang modal bahkan masyarakat umum. Pemerintah dalam hal ini menganggarkan pembiayaan ke darah-daerah melalui Anggaran Pendapatan dan Belanja Negara.APBN (Anggaran Belanja dan Pendapatan Negara merupakan rencana keuangan tahunan pemerintahan Negara Indonesia yang disetujui oleh Dewan Perwakilan Rakyat (DPR). APBN berisi daftar sistematis dan terperinci yang memuat rencana penerimaan dan pengeluaran Negara selama satu tahun anggaran. APBN mempunyai fungsi otorisasi, perencanaan, pengawasan, alokasi, distribusi, dan stabilisasi.Semua penerimaan yang menjadi hak pengeluaran yang 
menjadi kewajiban negara dalam suatu tahun anggaran harus dimasukan dalam APBN.Surplus penerimaan Negara dapat digunakan untuk membiayai pengeluaran Negara tahun anggaran berikutnya.Fungsi otorisasi, mengandung arti bahwa anggaran Negara menjadi dasar untuk melaksanakan pendapatan dan belanja pada tahun yang bersangkutan, dengan demikian pembelanjaan atau pendapatan dapat dipertanggungjawabkan kepada rakyat.Fungsi perencanaan mengandung arti bahwa anggaran Negara dapat menjadi pedoman bagi Negara untuk merencanakan kegiatan pada tahun tersebut.Bila suatu pembelanjaan telah direncanakan sebelumnya, maka Negara dapat membuat rencana-rencana untuk mendukung pembelanjaan tersebut.Fungsi pengawasan, berarti anggaran Negara harus menjadi pedoman untuk menilai apakah kegiatan penyelenggaraan pemerintah Negara sesuai dengan ketentuan yang telah ditetapkan.Fungsi alkoasi berarti bahwa kebijakan anggaran Negara harus memperhatikan rasa keadilan dan kepatutan.Fungsi stabilisasi memiliki makna bahwa anggaran pemerintah menjadi alat untuk memelihara dan mengupayakan keseimbangan fundamental perekonomian.

Dalam era desentralisasi fiskal sekarang ini, diharapkan adanya peningkatan pelayanan di berbagai sektor terutama sektor publik, dengan adanya peningkatan dalam layanan di sektor publik dapat meningkatkan daya tarik bagi investor untuk untuk menanamkan investasinya di daerah.Oleh karana itu, pergeseran komposisi belanja merupakan upaya logis yang dilakukan pemerintah daerah dalam rangka meningkatkan tingkat kepercayaan publik yang dapat dilakukan dengan peningkatan investasi modal dalam bentuk aset tetap, yakni peralatan, bangunan, infrastruktur dan harta tetap lainnya.Dengan meningkatnya pengeluaran modal diharapkan dapat meningkatkan pelayanan publik karena hasil dari pengeluaran belanja modal adalah meningkatnya aset tetap daerah yang merupakan prasyarat dalam memberikan pelayanan publik oleh pemerintah daerah. Pendapatan Asli Daerah (PAD) merupakan semua penerimaan daerah yang berasal dari sumber ekonomi asli daerah. Optimalisasi penerimaan Pendapatan Asli Daerah hendaknya didukung upaya pemerintah daerah dengan meningkatkan kualitas layanan publik (Mardiasmo,2002).

Menurut Halim (2009) permasalahan yang dihadapi daerah pada umumnya berkaitan dengan penggalian sumber-sumber pajak dan retribusi daerah yang merupakan salah satu komponen dari PAD masih belum memberikan konstribusi signifikan terhadap penerimaan daerah secara keseluruhan. Kemampuan perencanaan dan pengawasan keuangan yang lemah. Hal tersebut dapat mengakibatkan kebocorankebocoran yang sangat berarti bagi daerah. Peranan Pendapatan Asli Daerah dalam membiayai kebutuhan pengeluaran daerah sangat kecil dan bervariasi antar daerah, yaitu kurang dari 10\% hingga 50\%. Sebagian besar wilayah Provinsi dapat membiayai kebutuhan pengeluaran kurang dari 10\%. Distribusi pajak antar daerah sangat timpang karena basis pajak antar daerah sangat bervariasi. Peranan pajak dan retribusi daerah dalam pembiayaan yang sangat rendah dan bervariasi terjadi hal ini terjadi karena adanya perbedaanyang sangat besar dalam jumlah penduduk, keadaan geografis (berdampak pada biaya relative mahal) dan kemampuan masyarakat, sehingga dapat mengakibatkan biaya penyediaan pelayanan kepada masyarakat sangat bervariasi. Pendapatan asli daerah hanya merupakan salah satu komponen sumber penerimaan keuangan negara disamping penerimaan lainnya berupa dana perimbangan, pinjaman daerah dan lain-lain penerimaan yang sah. Keseluruhan bagian penerimaan tersebut setiap tahun tercermin dalam anggaran pendapatan dan belanja daerah. Meskipun PAD tidak seluruhnya dapat membiayai APBD, sebagaimana dikatakan oleh Santoso (1995:20) bahwa proporsi PAD terhadap total penerimaan tetap merupakan indikasi keuangan suatu pemerintah daerah.

Dalam praktiknya, transfer dari pemerintah pusat merupakan sumber pendanaan utama pemerintah daerah untuk membiayai operasional daerah, yang oleh pemerintah daerah "dilaporkan" di perhitungan anggaran. Tujuan dari transfer ini adalah untuk mengurangi kesenjangan fiskal antar pemerintah dan menjamin tercapainya standar pelayanan publik minimum di seluruh negeri (Maemunah,2006). Dalam Undang-undang No.32 Tahun 2004 disebutkan bahwauntuk pelaksanaan kewenangan pemerintah daerah, pemerintah pusat akan mentransfer Dana Perimbangan yang terdiri dari Dana Alokasi Umum (DAU), Dana Alokasi Khusus(DAK), dan Dana Bagi Hasil yang terdiri dari pajak dan sumber daya alam. Disamping dana perimbangan tersebut, pemerintah daerah mempunyai sumber pendanaan sendiri berupa Pendapatan Asli Daerah (PAD), pembiayaan, dan lain-lain pendapatan daerah. Pengggunaan dana-dana ini diserahkan kewenangannya sepenuhnya kepada pemerintah daerah untuk digunakan sebaik-baiknya dalam meningkatkan pelayanan kepada masyarakat bahkan membuka sumber-sumber ekonomi baru yang bisa 
menyerap tenaga kerja dari masyarakat yang ada di daerah sedangklan pemerintah pusat hanya bertugas sebagai fungsi kontrol.

Dalam rangka desentralisasi kepada pemerintah daerah dan pemerataan pembangunan di daerah maka pengalokasian anggaran pemerataan adalah dalam bentuk Dana Alokasi Umum (DAU) dan Dana Alokasi Khusus (DAK) yang bersumber dari Anggaran pendapatan Dan Belanja negara (APBN), Pembagian dana untuk daerah melalui bagi hasil berdasarkan daerah penghasil cenderung menimbulkan ketimpangan antar daerah. Daerahyang mempunyai potensi pajak dan Sumber Daya Alam (SDA) yang besarhanya terbatas pada sejumlah daerah tertentu saja. Peranan Dana Alokasi Umum terletak pada kemampuannya untuk menciptakan pemerataan berdasarkan pertimbangan atas potensi fiskal dan kebutuhan nyata dari masingmasing daerah (Undang- undang No.33 Tahun 2004). Sumber-sumber Pendapatan Daerah yang diperoleh dan dipergunakan untuk membiayai penyelenggaran urusan Pemerintah Daerah. Warsito, dkk (2008) mengatakan bahwa belanja daerah dirinci menurut urusan Pemerintah Daerah, organisasi, program, kegiatan, kelompok, jenis, obyek dan rincian obyek belanja. Belanja daerah dipergunakan dalam rangka mendanai pelaksanaan urusan pemerintah yang menjadi kewenangan Provinsi atau Kabupaten/Kota yang terdiri dari urusan wajib, urusan pilihan dan urusan yang penanganannya dalam bidang tertentu yang dapat dilaksanakan bersama antara Pemerintah Pusat dan Pemerintah Daerah. Belanja penyelenggaran urusan wajib diprioritaskan untuk melindungi dan meningkatkan kualitas kehidupan masyarakat dalam upaya memenuhi kewajiban daerah yang diwujudkan dalam bentuk peningkatan pelayanan dasar, pendidikan, kesehatan, fasilitas sosial dan fasilitas umum yang layak serta mengembangkan sistem jaminan sosial. Menurut Halim (2009) belanja tidak langsung merupakan belanja yangtidak memiliki keterkaitan secara langsung dengan pelaksanaan program dan kegiatan, terdiri dari belanja pegawai, belanja bunga, subsidi, hibah, bantuan sosial, belanja bagi hasil, bantuan keuangan dan belanja tidak terduga. Sedangkan belanja langsung merupakan belanja yang memiliki keterkaitan secara langsung dengan program dan kegiatan yang meliputi belanja pegawai, belanja barang dan jasa serta belanja modal.

\section{RumusanMasalah}

Berdasarkan uraian latar belakang permasalah yang dikemukakandiatas, maka dapat diidentifikasi suatu rumusan masalah sebagaiberikut:

1. $\quad$ Apakah Pendapatan Pajak Berpengaruh Terhadap Alokasi Belanja Langsung Kota Bitung ?.

2. Apakah pendapatan retribusi berpengaruh terhadap alokasi anggaran belanja langsung kota Bitung .?

3. Apakah Pejak retribusi dan belanja memberi dampak pada pertumbuhan ekonomi ?

\section{Tujuan}

Tujuan Penelitian ini adalah untuk membuktikan secara empiris pengaruh pendapatan pajak dan retribusi berpengaruh terhadap alokasi belanja langsung dan meber dampak pada pertumbuhan ekonomi kota Bitung.

\section{KegunaanPenelitian}

1. Bagi pemerintah daerah penelitian ini diharapkan dapat memberikan informasi pentingnya mengoptimalkan potensi local yang dimiliki daerah untuk peningkatan kulaitas pelayanan public demi kemajuan daerah.

2. Sebagai bahan referensi dan informasi bagi masyarakat dan mahasiswa/I yang ingin melakukan penelitian selanjutnya.

3. Untuk menambah dan memperkaya wawasan ilmiah penulis dalam disiplin ilmu yang penulis tekuni.

\section{LANDASAN TEORI \\ Pajak Daerah}

Kesit (2003) menyatakan bahwa pajak daerah merupakan iuran wajib yang dilakukan oleh orang pribadi atau badan tanpa imbalan langsung yang seimbang, yang dapat dipaksakan berdasarkan undangundang yang berlaku, yang hasilnya digunakan untuk membiayai penyelenggaraan pemerintahan daerah dan pembangunan daerah. Mardiasmo (1992) yang dimaksud dengan pajak daerah adalah pajak yang dipungut daerah berdasarkan peraturan pajak yang ditetapkan oleh daerah untuk kepentingan pembiayaan rumah tangga pemerintah daerah tersebut. 
Pajak daerah dalam hal ini ditetapkan oleh peraturan daerah. Untuk menerbitkan peraturan daerah peraturan daerah tentang pajak diharuskan memenuhi kriteria sebagai berikut :

1) Bersifat pajak dan bukan retribusi

2) Objek pajak terletak atau terdapat di wilayah daerah kabupaten

3) Objek dan dasar pengenaan pajak tidak bertentangan dengan kepentingan umum

4) Objek pajak bukan objek provinsi dan atau objek pajak pusat.

5) Potensinya memadai, berarti bahwa hasil pajak cukup besar sebagai salah satu sumber pendapatan daerah dan laju pertumbuhannya diperkirakan sejalan dengan laju pertumbuhan ekonomi.

6) Tidak memberikan dampak ekonomi yang negatif, yang berarti bahwa pajak tidak mengganggu alokasi sumber-sumber ekonomi secara efisien dan tidak merintangi arus sumber daya ekonomi antar daerah dan kegiatan ekspor-impor (Halim dan Mujib, 2009).

Pemerintah daerah harus memastikan bahwa penerimaan pajak lebih besar dari biaya pemungutannya. Selain itu, pemerintah daerah perlu menjaga stabilitas penerimaan pajak tersebut. Fluktuasi penerimaan pajak hendaknya dijaga tidak terlalu besar sebab jika sangat berfluktuasi juga kurang baik untuk perencanaan keuangan daerah (Mahmudi, 2010).

\section{Retribusi Daerah}

Menurut Sumitro (1979), pengertian retribusi secara umum adalah pembayaran-pembayaran kepada negara yang dilakukan oleh mereka yang menggunakan jasa-jasa negara. Pengertian yang hampir sama diberikan oleh Munawir (1980), retribusi daerah adalah iuran kepada pemerintah yang dapat dipaksakan dan jasa balik secara langsung dapat ditunjuk. Paksaan disini bersifat ekonomis karena siapa saja yang tidak merasakan jasa balik pemerintah dia tidak dikenakan iuran itu.

Retribusi daerah pada umumnya merupakan sumber pendapatan penyumbang PAD kedua setelah pajak daerah. Bahkan untuk beberapa daerah penerimaan retribusi daerah ini lebih tinggi daripada pajak daerah. Retribusi daerah memiliki karakteristik yang berbeda dengan pajak daerah. Pajak daerah merupakan pungutan yang dilakukan pemerintah daerah kepada wajib pajak atas pembayaran pajak tersebut. Sementara itu, retribusi daerah merupakan pungutan yang dilakukan pemerintah daerah kepada wajib retribusi atas pemanfaatan suatu jasa tertentu yang disediakan pemerintah. Jadi dalam hal ini terdapat imbalan langsung yang dapat dinikmati pembayar retribusi.

Terdapat tiga jenis retribusi daerah yaitu, retribusi jasa umum, retribusi jasa usaha, dan retribusi perizinan tertentu. Berbeda dengan pajak daerah yang bersifat tertutup, untuk retribusi ini pemerintah daerah masih diberi peluang untuk menambah jenisnya namun harus pula memenuhi persyaratan tertentu sebagaimana diatur undang-undang (Mahmudi, 2010)

Karena retribusi ini terkait dengan pelayanan tertentu, maka prinsip manajemen retribusi daerah yang paling utama adalah perbaikan pelayanan tersebut. Tentunya selain perbaikan pelayanan, pemerintah daerah juga perlu melakukan berbagai perbaikan sebagaimana halnya pajak daerah, seperti perluasan basis retribusi, pengendalian atas kebocoran penerimaan retribusi, dan perbaikan administrasi pemungutan retribusi (Mahmudi, 2009).

\section{Belanja Daerah}

Menurut Peraturan Menteri Dalam Negeri No 27 Tahun 2013 Belanja daerah harus digunakan untuk pelaksanaan urusan pemerintahan yang menjadi kewenangan pemerintah provinsi dan pemerintah Kabupaten/Kota yang terdiri dari urusan wajib dan urusan pilihan yang ditetapkan dengan ketentuan peraturan perundang-undangan. Belanja penyelenggaraan urusan wajib diprioritaskan untuk melindungi dan meningkatkan kualitas kehidupan masyarakat dalam upaya memenuhi kewajiban daerah yang diwujudkan dalam bentuk peningkatan pelayanan dasar, pendidikan, kesehatan, fasilitas sosial dan fasilitas umum yang layak serta mengembangkan sistem jaminan sosial. Pelaksanaan urusan wajib dimaksud berdasarkan Standar Pelayanan Minimal (SPM) yang telah ditetapkan. Pemerintah daerah menetapkan target capaian kinerja setiap belanja, baik dalam konteks daerah, satuan kerja perangkat daerah, maupun program dan kegiatan, yang bertujuan untuk meningkatkan akuntabilitas perencanaan anggaran dan memperjelas efektifitas dan efisiensi penggunaan anggaran. Program dan kegiatan harus memberikan informasi yang jelas dan terukur 
serta memiliki korelasi langsung dengan keluaran yang diharapkan dari program dan kegiatan dimaksud ditinjau dari aspek indikator, tolak ukur dan target kinerjanya. Dalam Peraturan Menteri Dalam Negeri No 27 Tahun 2013 tentang Belanja Tidak Langsung dan Belanja Langsung.

\section{Pertumbuhan Ekonomi}

Secara umum, pertumbuhan ekonomi didefenisikan sebagai peningkatan kemampuan dari suatu perekonomian dalam memproduksi barang-barang dan jasa-jasa. Pertumbuhan ekonomi adalah salah satu indikator yang amat penting dalam melakukan analisis tentang pembangunan ekonomi yang terjadi pada suatu negara. Pertumbuhan ekonomi menunjukkan sejauh mana aktivitas perekomian akan menghasilkan tambahan pendapatan masyarakat pada suatu periode tertentu. Karena pada dasarnya aktivitas perekonomian adalah suatu proses penggunaan faktor-faktor produksi untuk menghasilkan output, maka proses ini pada gilirannya akan menghasilkan suatu aliran balas jasa terhadap faktor produksi yang dimiliki oleh masyarakat. Dengan adanya pertumbuhan ekonomi maka diharapkan pendapatan masyarakat sebagai pemilik faktor produksi juga akan meningkat.

Dengan perkataan lain bahwa pertumbuhan ekonomi lebih menunjuk kepada perubahan yang bersifat kuantitatif (quantitative change) dan biasanya diukur dengan menggunakan data Produk Domestik Bruto (PDB) atau pendapatan atau nilai akhir pasar (total market value) dari barang-barang akhir dan jasa-jasa (final goods and services) yang dihasilkan dari suatu perekonomian selama kurun waktu tertentu (biasanya satu tahun).

Perlu diketahui bahwa pertumbuhan ekonomi berbeda dengan pembangunan ekonomi, kedua istilah ini mempunyai arti yang sedikit berbeda. Kedua-duanya memang menerangkan mengenai perkembangan ekonomi yang berlaku. Tetapi biasanya, istilah ini digunakan dalam konteks yang berbeda. Pertumbuhan selalu digunakan sebagai suatu ungkapan umum yang menggambarkan tingkat perkembangan sesuatu negara, yang diukur melalui persentasi pertambahan pendapatan nasional riil. Istilah pembangunan ekonomi biasanya dikaitkan dengan perkembangan ekonomi di negara-negara berkembang. Dengan perkataan lain, dalam mengartikan istilah pembangunan ekonomi, ahli ekonomi bukan saja tertarik kepada masalah perkembangan pendapatan nasional riil, tetapi juga kepada modernisasi kegiatan ekonomi, misalnya kepada usaha merombak sektor pertanian yang tradisional, masalah mempercepat pertumbuhan ekonomi dan masalah perataan pembagian pendapatan (Sukirno, 2006:423)

\section{METODE PENELITIAN}

\section{Pengertian Path Analysis}

"Path analysis merupakan perluasan dari regresi linier berganda, dan yang memungkinkan analisis model-model yang lebih kompleks" (Streiner, 2005) "path analysis ialah suatu teknik untuk menganalisis hubungan sebab akibat yang terjadi pada regresi berganda jika variabel bebasnya mempengaruhi variabel tergsntung tidak hanya secara langsung" (Robert D. Retherford 1993) Sedangkan menurut Paul Webley (1997) "path analysis merupakan pengembangan langsung bentuk regresi berganda dengan tujuan untuk memberikam estimasi tingkat kepentingan ( magnitude) dan signifikasi (significance) hhubungan sebab akibat hipotetikal dalam seperangkat variabel"

David Garson (2003) dari North California State University mengidentifikasikan model analysis path sebagai " perluasan regresi yang digunakan untuk menguji keselarasan matriks kolerasi dengan dua atau lebih model hubungan sebab akibat yang dibandingkan oleh peneliti"

Modelnya digambarkan dalam bentuk lingkaran dan panah dimana anak panah yang tunggal menunjukan sebagai penyebab. Regresi dikenakan pada masing-masing variabel dalam suatu model sebagai penyebab. Pembobotan regresi diprediksikan dalm suatu model yang dibandingkan dengan matriks kolerasi yang diobservasi untuk semua variabel dan dilakukan juga perhitungan uji keselarasan statistik. Dari definisi diatas dapat sismpulkann bahwa sebenarnya path analysis dapat dikatakan sebagai kepanjangan dari analisis regresi berganda, meski didasarkan sejarah terdapat perbedaan dasar antara path analysis yang bersifat independen terhadap prosedur statistic dalam menentukan hubungan sebab akibat sedang regresi linier memang merupakan prosedur stastik yang digunakan untuk menganalisis hubungan sebab akibat antara variabel yang dikaji. 


\section{Tujuan Path Analysis}

Tujuan menggunajkan path analysis diantaranya ialah untuk:

1. Melihat hubangan antara variabel dengan didasarkan pada model apriori

2. Meerangkan mengapa variabel-variabel berkolerasi dengan menggunakan suatu model yang berurutan secara temporer.

3. Menggambar dan menguji suatu model matematis dengan menggunakan persamaan yang mendasarinya.

4. Mengidentifikasi jalur penyebab suatu variabel tertentu terhadap vaariabel-variabel lain yang dipengaruhinya.

5. Menghitung besarnya pengaruh satu variabel independen exogenous atau lebih terhadap variabel dependen endogenous lainya.

Aplikasi model yang digunakan dalam penelitian ini adalh "APLIKASI MODEL MEDIASI MELALUI VERIABEL PERANTARA"

Untuk model yang akan digunakan adalah dua veriabel independen yang berfungsi sebagai variabel exogenous dan dua variiabel dependen yang berfungsi sebagai variabel endogenous.sebagai variabel exogenous ialah Pendapatan pajak dan pendapatan retribusi sedangkan sebagai variabel endogenous pertama yang berfungsi sebagai variabel perantara ialah belanja langsung dan variabel endogenous yang kedua ialah pertumbuhan ekonomi. Hubungan antara variabel tersebut jika digambarkan kedalam model diagram jalur menjadi seperti di bawah ini :

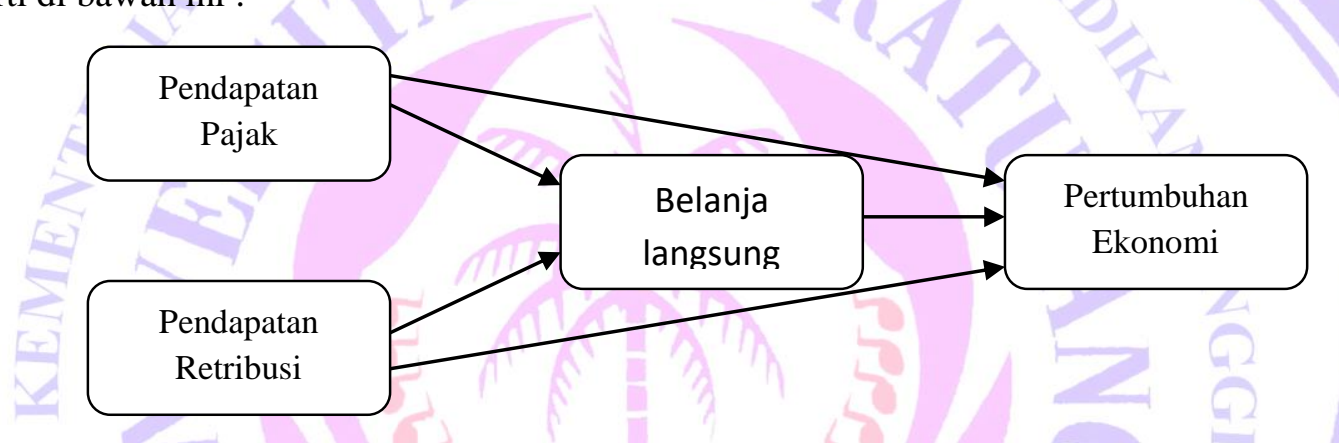

Gambar 1 Diagram Jalur Pengaruh Pendapatan Pajak dan Pendapatan Retribusi terhadap Belanja Langsung dan dampaknya terhadap pertumbuhan ekonomi

\section{HASIL PENELITIAN DAN PEMBAHASAN}

\section{Hasil Uji dan Deskripsi Statistik \\ Diagram Jalur penelitian}

Dimana dibawah ini merupakan Diagram penelitian yang di lakukan oleh peneliti dalam mencari Pengaruh yang ditimbulkan oleh Variabel Dependen Exogenus terhadap Variabel Independen Exogenus.

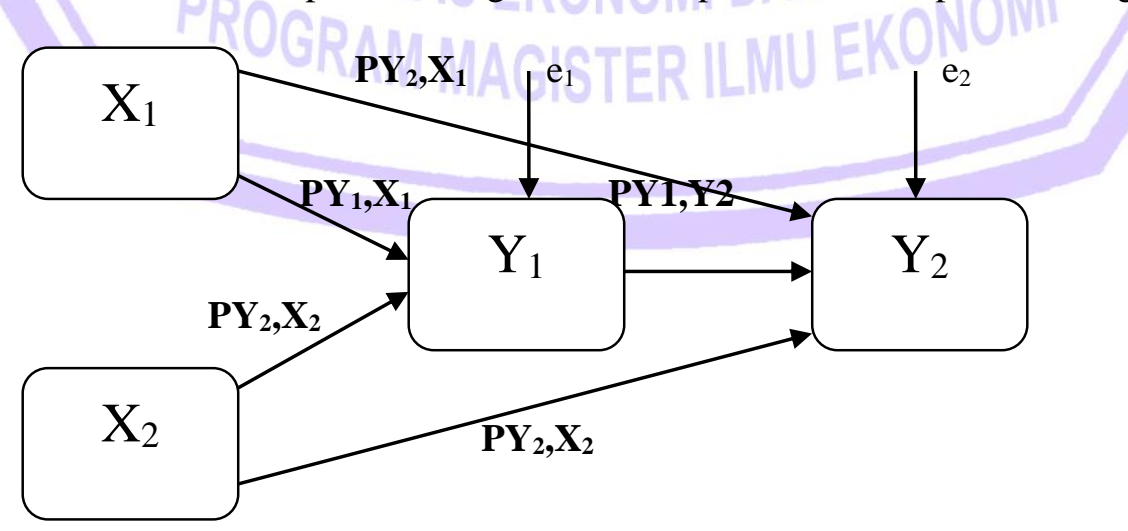


Gambar 2 Diagram Jalur Pengaruh Pendapatan Pajak dan Retribusi terhadap belanja langsung Dan dampaknya terhadap pertumbuhan ekonomi.

Diagram jalur di atas menunjukan dimana

$\mathrm{X}_{1}$ sebagai Variabel Independen Exogenus Pendapatan Pajak

$\mathrm{X}_{2}$ sebagai Variabel Independen Exogenus Pendapatan Retribusi

$\mathrm{Y}_{1}$ sebagai Variabel Dependen Endogenus Belanja Langsung

$\mathrm{Y}_{2}$ sebagai Variabel Endogenus Pertumbuhan Ekonomi

Diagram jalur diatas mempunyai dau persamaan struktural. Persamaan strukturalnya dapat dilihat seperti dibawah ini

$\mathrm{Y}_{1}=\mathrm{PY} 1, \mathrm{X} 1+\mathrm{PY} 1, \mathrm{X} 2+\mathrm{e}_{1}$

$\mathrm{Y}_{2}=\mathrm{PY}_{2}, \mathrm{X}_{1}+\mathrm{PY}_{2}, \mathrm{X}_{2}+\mathrm{PY}_{2}, \mathrm{Y}_{1}+\mathrm{e}_{2}$

\section{Pengujian Asumsi klasik}

\section{Perhitungan Sub Struktur I}

Tabel 1. Uji Multikolerasi

\begin{tabular}{|ll|l|l|}
\hline Model & Collinearity Statistics & \\
\cline { 3 - 4 } & (Constant) & VIF & Tolerance \\
\hline \multirow{3}{*}{1} & Retribusi & 331 & 331 \\
\cline { 4 - 4 } & Pajak & .331 & .331 \\
\hline
\end{tabular}

a. Dependent Variable: Belanja Langsung

Sumber Data : pengolahan data 2016

Dilihat dari tabel 4.2 Coefficients nilai VIF pada Output menunjukkan keberadaan multikolinearitas.

Bila VIF $<10,00$ maka tidak terjadi gejala Multikolerasi

Bila VIF > 10,00 maka terjadi gejala Multikolerasi

Dengan Hasil :

Nilai Tolerance : X1 Pendapatan Pajak $=0,331$

$\mathrm{X} 2$ Pendapatann Retribusi $\quad=0,331$

Nilai VIF : X1 Pendapatan Pajak $\quad=3.018$

X2 Pendpatan Retribusi $\quad=3.018$

Dari hasil perhitungan di atas dapat dilihat bahwa nilai VIF kedua variable independent berada pada angka dibawah 10 hal ini menunjukan bahwa tidak terjadi gejala multikolinearitas sehingga data penelitian layak dan dapat digunakan.

Gambar 3. Diagram Uji Heterokoledasitas

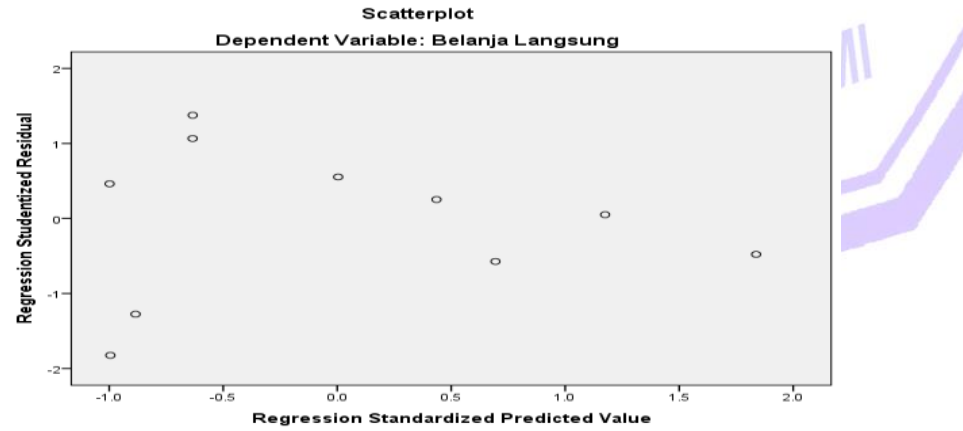

Dari diagram diatas tersebut terlihat bahwa penyebaran residual tidak teratur. Hal tersebut terlihat pada plot yang terpancar dan tidak membentuk pola tertentu. Dengan hasil demikian, kesimpulan yang biasa diambil adalah bahwa tidak terjadi gejala homokedastisitas atau persamaan regresi memenuhi asumsi heterokedatisitas. 
Tabel 2 Uji Autokorelasi

Model Summary ${ }^{\mathrm{b}}$

\begin{tabular}{|l|l|l|l|l|}
\hline \multirow{2}{*}{ Model } & \multicolumn{2}{|l|}{ Change Statistics } & Durbin-Watson \\
\cline { 2 - 4 } & df1 & df2 & Sig. F Change & \\
\hline 1 & $2^{\mathrm{a}}$ & $7^{\mathrm{a}}$ &, 013 & 1,821 \\
\hline
\end{tabular}

a. Predictors: (Constant), Pajak, Retribusi

b. Dependent Variable: Belanja Langsung

Sumber Data : pengolahan data 2015

Pada analisis regresi telihat bahwa nilai DW 1.821 dan nilai DL 0.455, dan DU 2,287. DL < DW < DU yakni $0.455 \mathrm{DL}, 1.821 \mathrm{DW}, 2.287 \mathrm{DU}$. berada pada antara DL dan DU dan berada pada titik keraguraguan. Maka dapat disimpulkan bahwa terdapat gejala autokorelasi yang lemah.

Hasil Perhitungan (output) untuk substruktur satu dengan menggunakan SPSS 20 adalah sebagai berikut :

Tabel 3 Correlations

\begin{tabular}{|ll|l|l|l|}
\hline & & $\begin{array}{l}\text { Belanja } \\
\text { Langsung }\end{array}$ & Retribusi & Pajak \\
\hline \multirow{3}{*}{ Pearson Correlation } & Belanja Langsung & 1.000 & .739 & .836 \\
& Retribusi & .739 & 1.000 & .818 \\
& Pajak & .836 & .818 & 1.000 \\
Sig. (1-tailed) & Belanja Langsung & & .007 & .001 \\
& Retribusi & .007 &. & .002 \\
& Pajak & .001 & .002 &. \\
$\mathrm{~N}$ & Belanja Langsung & 10 & 10 & 10 \\
& Retribusi & 10 & 10 & 10 \\
& Pajak & 10 & 10 & 10 \\
\hline
\end{tabular}

Sumber Data : pengolahan data 2015

Dari tabel 3 Correlations diatas menunjukan bahwa Koefisien Korelasi Pearson Pendapatan Pajak dengan alokasi belanja langsung adalah 0,836 dengan nilai sig 0,001, koefisien korelasi antara pendapatan retribusi dan belanja langsung. Dari hasil tabel Correlations diatas menunjukan 0,739 dengan nilai signifikan 0,007.. Dengan demikian dilihat dalam kondisi tersebut dimana nilai signifikan < 0,05. Maka kesimpulan yang diambil adalah $\mathrm{H} 0$ di tolak, dan $\mathrm{H} 1$ di terima. Yang berarti Koefisien Korelasi adalah signifikan secara statistik.

Tabel 4 Model Summary(b)

\begin{tabular}{|c|c|c|c|c|c|c|}
\hline \multirow[t]{2}{*}{ Model } & \multirow[t]{2}{*}{$\mathrm{R}$} & \multirow{2}{*}{$\begin{array}{l}\mathrm{R} \\
\text { Square }\end{array}$} & \multirow{2}{*}{$\begin{array}{l}\text { Adjusted R } \\
\text { Square }\end{array}$} & \multirow{2}{*}{$\begin{array}{l}\text { Std. Error of } \\
\text { the Estimate }\end{array}$} & \multicolumn{2}{|c|}{ Change Statistics } \\
\hline & & & & & $\begin{array}{l}\text { R Square } \\
\text { Change }\end{array}$ & F Change \\
\hline 1 & $842^{\mathrm{a}}$ & 708 & 625 & 14211 & 708 & 8.494 \\
\hline
\end{tabular}

a Predictors: (Constant), Pajak, Retribusi

b Dependent Variable: Belanja Langsung

Sumber Data : pengolahan data 2016

Dalam melihat pengaruh Variabel Independen Exogenus pendapatan pajak dan retribusi secara gabungan terhadap variabel Dependen Endogenus belanja langsung dapat dilihat dari Tabel 4.5 Model Summary dibawah ini, pada nilai $R$ square. Besarnya $R$ square $\left(R^{2}\right)$ pada tabel dibawah ini adalah 0,708 . Angka tersebut mempumpunyai makna Besarnya pengaruh Variabel indeependen exogenous pendapatan pajak dan retribusi terhadap variabel dependen endogenus alokasi belanja langsung secara gabungan. Dalam menghitung Koefisien Determinasi (KD) dapat diketahui dengan rumus KD = R2 x 100\%, KD = 0,708 x $100 \%, \mathrm{KD}=70,8 \%$ Besarnya pengaruh Variabel Independen Exogenous pendapatan pajak dan pendapatan retribusi terhadap Variabel Dependen Endogenus belanja langsung secara gabungan adalah 70,8\%. 
Dan pengaruh di luar model dapat di hitung dengan rumus : e $=1-\mathrm{R}^{2}, \mathrm{e}=1-0,708, \mathrm{e}=0,292 \mathrm{x}$ $100 \%, \mathrm{e}=29,2 \%$. Yang berarti $29,2 \%$ berarti besarnya faktor lain yang mempengaruhi diluar model yang di teliti. Artinya besarnya pengaruh variabel independen eksogenus pajak dan retribusi terhadap variabel dependen endogenus belanja langsung adalah sebesar 70,8 \%, sedangkan pengaruh sebesar 29,2 \% disebabkan oleh variabel di luar model yang di teliti. Hal ini mengindikasikan bahwa belanja langsung dipengaruhi sebagian besar dari pendapatan daerah dalam bentuk pajak dan retribusi yang berarti belanja pembangunan yang dilakukan oleh daerah bergantung pada pendapatan pajak maupun retribusi.

\section{Pengaruh variabel independen exogenous Pajak dan Retribusi secara parsial terhadap variabel} dependen endogenus Belanja Langsung.

Besarnya pengaruh variabel independen exogenous Pajak dan Retribusi terhadap variabel dependen endogenus Belanja Langsung secara Parsial dapat dilihat dari nilai Beta atau Standardized Coefficients .dan untuk pengujian digunakan nilai t. Dapat dilihat pada Tabel 5 dibawah ini

Tabel 5 Coefficients(a)

\begin{tabular}{|ll|l|l|l|l|l|}
\hline \multicolumn{2}{|l|}{ Model } & \multicolumn{2}{|l|}{ Unstandardized Coefficients } & $\begin{array}{l}\text { Standardized } \\
\text { Coefficients }\end{array}$ & S & \\
\cline { 2 - 5 } & & B & Std. Error & Beta & & \\
\hline \multirow{2}{*}{1} & (Constant) & 5.152 & 1.559 & & 3.305 & .013 \\
& Retribusi & 130 & .274 & .168 & .473 & .650 \\
& Pajak & .488 & .248 & .699 & 1.970 & .090 \\
\hline
\end{tabular}

a. Dependent Variable: belanja langsung

Sumber Data : pengolahan data 2016

Pengaruh Variabel Independen Exogenous Pajak terhadap Variabel Dependen Endogenus Belanja Langsung.

Untuk melihat apakah ada Pengaruh Linier Variabel Independen Exogenus Pajak terhadap Variabel Dependen Endogenus belanja langsung. Dapat dilihat pada tabel 5 Coefficients(a) Dengan Analisis :

Dalam perhitungan SPSS yang tertera pada tabel Coefficients di atas dimana tabel $\mathrm{t}$ adalah untuk menunjukan bahwa adanya Pengaruh linier antara Variabel Independen Exogenus Pendapatan Pajak terhadap Variabel Dependen Endogenus Belanja Langsung ialah 1,970.

Hasil dari perhitungan dengan SPSS menunjukan angka $\mathrm{t}$ hitung sebesar $1,970<\mathrm{t}$ tabel sebesar 2,447. Dengan demikian keputusanya ialah HO diterima, dan H1 ditolak. Artinya tidak ada hubungan linier antara Variabel Independen Exogenus pendapatan Pajak terhadap Variabel Dependen Endogenus Belanja Langsung. Maka Variabel Independen Exogenus Pendapatan Pajak tidak berpengaruh terhadap Variabel Dependen Endogenus Belanja Langsung.

Besarnya Koefisien Beta pada tabel 5 di atas (dalam kolom Standardized Coefficient Beta) sebesar 0,699 atau jika dibuat persen menjadi sebesar 69,9\% menunjukan bahwa pengaruh sebesar ini tidak signifikan karena nilai signifikansi / probabilitas hasil yang tertera pada kolom Sig 0,90>0,05. Hal ini mengindikasikan bahwa pendapatan pajak mempunyai pengaruh yang cukup besar bagi alokasi anggaran belanja langsung namun tidak secara signifikan.

Pengaruh antara variabel Independen Exogenus Pendapatan Retribusi terhadap Variabel Dependen Endogenus Belanja Langsung.

Untuk melihat apakah ada hubungan Linier Variabel Independen Exogenus Pendapatan Retribusi terhadap Variabel Dependen Endogenus Belanja Langsung.

Nilai t hasil perhitungan dengan menggunakan SPSS yang tertera pada kolom $t$ pada tabel Coefficients diatas untuk menunjukan adanya hubungan Linier antara Variabel Independen Exogenus Pendapatan Retribusi dengan Variabel Dependen Endogenus Belanja Langsung adalah 0,473.

Hasil dari perhitungan dengan SPSS menunjukan angka $t$ hitung sebesar $0,473<\mathrm{t}$ tabel sebesar 2,447. Dengan demikian keputusanya ialah HO diterima dan H1 ditolak. Artinya tidak ada pengaruh linier antara Variabel Independen Exogenus pendapatan retribusi terhadap Variabel Dependen Endogenus Belanja 
Langsung. Maka Variabel Independen Exogenus pendapatan Retribusi tidak berpengaruh terhadap Variabel Dependen Endogenus Belanja Langsung.

Besarnya pengaruh Variabel Independen Exogenus Pendapatan retribusi terhadap Variabel Dependen Endogenus Belanja Langsung diketahui dari nilai Koefisien Beta (dalam kolom Standardized Coefficients Beta) ialah 0,168 atau jika dibuat persen 16,8\% pengaruh sebesar ini tidak Signifikan karena nilai signifikansi / probabilitas hasil yang tertera pada kolom Sig 0,650>0,05.

\section{Melihat Kelayakan Model Regresi}

untuk mengetahui model regresi yang telah dibuat sudah benar adalah dengan menggunakan pengujian dengan menggunakan pengujian dengan dua cara, yaitu Pertama menggunakan nilai $\mathrm{F}$ pada tabel keluaran ANOVA, dan Kedua dengan cara menggunakan nilai Probabilitas / nilai Sig pada tabel keluaran ANOVA.

Tabel 6 ANOVA(b)

\begin{tabular}{|ll|l|l|l|l|l|}
\hline Model & & Sum of Squares & df & Mean Square & F & Sig. \\
\hline \multirow{3}{*}{$\begin{array}{l}1 \\
1\end{array}$} & Regression & 343 & 2 & 172 & 8.494 & $.013^{\mathrm{b}}$ \\
& $\begin{array}{l}\text { Residual } \\
\text { Total }\end{array}$ & .141 & 7 & .020 & & \\
\hline
\end{tabular}

a. Dependent Variable: Belanja Langsung

b. Predictors: (Constant), Pajak, Retribusi

Sumber Data : pengolahan data 2016

Menghitung nilai $\mathrm{F}$ tabel dengan Ketentuan besar nilai taraf Signifikansi sebesar 0,05 dan Nilai Degree Of Freedom dengan ketentuan Numerator / Vektor 1: Jumlah Variabel -1 atau $3-1=2$, dan dumerator / Vektor 2 : jumlah kasus-jumlah variabel atau $9-3=6$. Dengan ketentuan terdebut diperoleh angka $\mathrm{F}$ tabel sebesar 6,314. Hasil perhitungan dengan SPSS didapatkan angka $\mathrm{F}$ hitung sebesar 8,494 > F tabel sebesar 6,314. Dengan demikian H0 ditolak, dan H1 diterima. Artinya ada hubungan linier antara Variabel Independen Eksogenus Pendapatan Pajak dan Retribusi dengan Variabel Dependen Endogenus Belanja Langsung. Dengan nilai Sig 0,013 Kesimpulan adalah model regresi di atas sudah layak dan benar.

\section{Perhitungan Sub Struktur II}

\begin{tabular}{|c|c|c|c|c|c|c|}
\hline \multirow[t]{2}{*}{ Model } & \multicolumn{2}{|l|}{$\begin{array}{l}\text { Unstandardized } \\
\text { Coefficients }\end{array}$} & \multirow{2}{*}{$\begin{array}{l}\text { Standardized } \\
\text { Coefficients } \\
\text { Beta }\end{array}$} & \multirow[t]{2}{*}{$\mathrm{t}$} & \multirow[t]{2}{*}{ Sig. } & \multirow{2}{*}{$\begin{array}{l}\text { Collinearity } \\
\text { Statistics } \\
\text { VIF }\end{array}$} \\
\hline & B & $\begin{array}{l}\text { Std. } \\
\text { Error }\end{array}$ & & & & \\
\hline 1 (Constant) & -8102.403 .005 & .575 & & -3.677 & .010 & \\
\hline $\begin{array}{l}\text { Belanja } \\
\text { Langsung }\end{array}$ & 868.852 & .058 & .853 & 2.601 & .041 & 3.427 \\
\hline Retribusi & 480.029 & .068 & -.611 & -1.962 & .099 & 3.115 \\
\hline Pajak & 363.274 & .069 & .512 & 1.333 & .231 & 4.691 \\
\hline
\end{tabular}

Sumber Data : pengolahan data 2016

Dilihat dari Tabel Coefficients ${ }^{\mathrm{a}}$ nilai VIF paa out-put menunjukan keberaadaan Multikolinearitas tidak signifikan, artinya tidak ada indikasi Multikolinearitas dalam model. Ini ditunjukan dengan nilai VIF berturut-turut untuk X1 Pajak, X2 Retribusi, dan X3 Belanja Langsung. Adalah lebih kecil dari 10,0.

\section{Pengaruh Variabel Independen Eksogenus Pendapatan Pajak, Retribusi dan Belanja Langsung Secara Gabungan Terhadap Variabel Dependen Endogenus Pertumbuhan Ekonomi.}

Untuk melihat hubungan pengaruh variabel Independen Exogenus Pajak, Retribusi dan Belanja Lansung terhadap Pertumbuhan Ekonomi (PDRB) secara gabungan dapat dilihat pada Tabel Model Summary, dalam angka R square di bawah ini. 
Tabel 8 Model Summary(b)

\begin{tabular}{|l|l|l|l|l|l|}
\hline Model & R & R Square & $\begin{array}{l}\text { Adjusted } \\
\text { R Square }\end{array}$ & $\begin{array}{l}\text { Std. Error of } \\
\text { the Estimate }\end{array}$ & $\begin{array}{l}\text { Durbin- } \\
\text { Watson }\end{array}$ \\
\hline 1 & $.901(\mathrm{a})$ & .812 & .717 & 125.52030 & 2.303 \\
\hline
\end{tabular}

Sumber Data : pengolahan data 2016

Besarnya pengaruh Rsquare $\left(\mathrm{R}^{2}\right)$ pada tabel diatas adalah 0,812 . Angka tersebut mempunyai makna besarnya pengaruh variabel independen exogenous Pajak, Retribusi dan Belanja Langsung terhadap Pertumbuhan Ekonomi secara gabungan. dalam menghitung Koefisien Determinasi (KD) dapat di hitung dengan Rumus sebagai berikut. $\mathrm{KD}=\mathrm{R} 2 \times 100 \%, \mathrm{KD}=0,812 \times 100 \%, \mathrm{KD}=81,2 \%$. Angka $81,2 \%$ mempunyai makna besarnya pengaruh Variabel Independen Exogenus Pendapatan Pajak, Retribusi dan Belanja Langsung terhadap Pertumbuhan Ekonomi secara gabungan. sedangkan sisanya dapat dihitung dengan menggunakan rumus sebagai berikut : $\mathbf{e}=1-\mathrm{R} 2, \mathbf{e}=1-0,812, \mathbf{e}=0,188, \quad \mathbf{e}=0,188 \times 100 \%, \mathbf{e}=$ $18,8 \%$. Variabelitas Pertumbuhan Ekonomi yang dapat diterangkan dengan menggunakan Variabel Independen Exogenus Pendapatan Pajak, Retribusi dan Belanja Langsung adalah sebesar 81,2 \%, sedangkan besarnya pengaruh dari Variabel diluar model adalah sebesar $18,8 \%$.

Pengaruh Variabel Independen Exogenus Pajak, Retribusi dan Belanja Langsungsecara Parsial terhadap Variabel Dependen Enradogenus Pertumbuhan Ekonomi.

Besarnya pengaruh Variabel Independen Exogenus Pajak, Retribus dan Belanja Langsung terhadap Pertumbuhan Ekonomi secara Parsial.

\section{Tabel 9 Coefficients(a)}

\begin{tabular}{|ll|l|l|l|l|l|}
\hline Model & \multicolumn{2}{|l|}{ Unstandardized Coefficients } & $\begin{array}{l}\text { Standardized } \\
\text { Coefficients }\end{array}$ & & \multirow{2}{*}{ Sig. } \\
\cline { 3 - 5 } & & $\mathrm{B}$ & Std. Error & Beta & & \\
\hline \multirow{4}{*}{1} & (Constant) & -8102.403 & 2203.309 & & -3.677 & .010 \\
& Belanja Langsung & 868.446 & 333.852 & .853 & 2.601 & .041 \\
& Retribusi & -480.029 & 245.859 & -.611 & -1.952 & .099 \\
& Pajak & 363.374 & 272.572 & .512 & 1.333 & 231 \\
\hline
\end{tabular}

a Dependent Variable: Pertumbuhan Ekonomi

Sumber Data : pengolahan data 2016

Pengaruh antara variabel Independen Exogenus Pajak dengan Variabel Dependen Endogenus Pertumbuhan Ekonomi.

Dari hasil perhitungan dengan menggunakan SPSS yang tertera pada kolom t pada tabel Coefficients diatas untuk menunjukan adanya hubungan linier antara Variabel Independen Exogenus Pajak dengan Variabel Dependen Endogenus Pertumbuhan Ekonomi ialah sebesar 1,333

Hasil dari perhitungan dengan menggunakan SPSS menunjukan angka t hitung sebesar 1,198 < 2,571, dengan demikian keputusanya adalah H0 diterima, dan H1 ditolak. Artinya tidak ada hubungan linier antara Variabel Independen Pajak terhadap Variabel Dependen Endogenus Pertumbuhan Ekonomi. Nilai koefisien Beta ( dalam kolom Standardized Coefficient Beta) sebesar 0,100 atau jika dibuat dalam persen menjadi 100\% menunjukan bahwa pengaruh sebesar ini tidak signifikan karena nilai signifikansi / probabilitas hasil perhitungan yang tertera dalam kolom sig sebesar $0,231>0,05$.

Pengaruh antara Variabel Independen Exsogenus Retribusi terhadap Variabel Independen Endogenus Pertumbuhan Ekonomi.

Dari hasil perhitungan dengan menggunakan SPSS yang terterah pada kolom t pada tabel Coefficients di atas untuk menunjukan hubungan linier antara Variabel Independen Exogenus Retribusi terhadap variabel Dependen Endogenus Pertumbuhan Ekonomi adalah -1.952.

Menentukan taraf signifikansi sebesar 0,05 dan Degree Of Freedom (DF). DF $=n-(K+1)$ atau $9-(3+1)=5$ dari ketentuan tersebut diperoleh angka t tabel sebesar 2,571. Hasil perhitungan dengan menggunakan SPSS 
menunjukan angka $\mathrm{t}$ hitung kecil $-1,952<\mathrm{t}$ tabel sebesar 2,571. Dengan demikian keputusanya adalah $\mathrm{H} 1$ ditolak dan H0 diterima, artinya tidak ada hubungan linier antara variabel Independen Exogenus Retribusi dengan Variabel Dependen Endogenus Pertumbuhan Ekonomi.

Nilai koefisien Beta (dalam kolom Standardized Coefficient Beta) sebesar -0,611 atau jika dibuat dalam persen sebesar $-61 \%$ menujukan bahwa pengaruh sebesar ini tidak signifikan karena nilai signifikansi / probabilitas hasil perhitungan yang tertera dalam kolom Sig sebesar sebesar 0,099 > 0,05

\section{Pengaruh antara Variabel Independen Exsogenus Belanja Langsung terhadap Variabel Independen Endogenus Pertumbuhan Ekonomi.}

Dari hasil perhitungan dengan menggunakan SPSS yang tertera pada kolom t pada tabel Coefficients di atas untuk menunjukan hubungan linier antara Variabel Independen Exogenus Belanja Langsung terhadap variabel Dependen Endogenus Pertumbuhan Ekonomi adalah 2.601.

Hasil perhitungan dengan menggunakan SPSS menunjukan angka $t$ hitung sebesar $2.601>t$ tabel sebesar 2,571. Dengan demikian keputusanya adalah H1 diterima dan H0 ditolak, artinya ada hubungan linier antara variabel Independen Exogenus Belanja Langsung dengan Variabel Dependen Endogenus Pertumbuhan Ekonomi. Maka variabel Exogenus Independen Endogenus Belanja Langsung mempengaruhi Variabel Dependen Endogenus Pertumbuhan Ekonomi. Nilai koefisien Beta (dalam kolom Standardized Coefficient Beta) sebesar .853 atau jika dibuat dalam persen sebesar 85,3\% menujukan bahwa variabel Independen Exogenus Belanja Langsung berpengaruh terhadap Variabel Dependen Endogenus Pertumbuhan Ekonomi. dengan demikian pengaruh sebesar ini signifikan karena nilai signifikansi / probabilitas hasil perhitungan yang tertera dalam kolom Sig sebesar sebesar 0,041.

\section{Melihat Kelayakan Model Regresi Struktur II}

Untuk mengetahuimodel Regresi yang dibuat telah benar adalah dengan menggunakan Pengujian dua cara yaitu pertama menggunakan nilai $\mathrm{F}$ pada tabel keluaran ANOVA, dan kedua dengan cara menggunakan nilai Probabilitas nilai Sig pada tabel keluaran ANOVA.

Tabel 10 ANOVA(b)

\begin{tabular}{|c|c|c|c|c|c|c|}
\hline Model & & Sum of Squares & Df & Mean Square & $\mathrm{F}$ & Sig. \\
\hline \multirow{3}{*}{1} & Regression & 407154.026 & 3 & 135718.009 & 8.614 & $.014^{\mathrm{b}}$ \\
\hline & Residual & 94532.074 & 6 & 15755.346 & & \\
\hline & Total & 501686.100 & 9 & & & \\
\hline
\end{tabular}

a. Dependent Variable: Pertumbuhan Ekonomi

b. Predictors: (Constant), Pajak, Retribusi, Belanja Langsung

Nilai F hitung dari keluaran SPSS ialah 8.614. Menghitung nilai $\mathrm{F}$ tabel dengan ketentuan nilai besar nilai taraf signifikasi sebesar 0,05 dan nilai DF / Vektor 1 : jumlah variabel -1 atau 3-1 $=2$ dan dumerator Vektor : jumlah kasus - jumlah variabel atau $9-3=6$ dengan ketentuan tersebut diperoleh angka $F$ tabel sebesar 5,41

Hasil perhitungan didapat angka F hitung sebesar 8.614 > F tabel sebesar 5,41. Dengan demikian H0 ditolak, dan H1 diterima dengan demikian Ada pengaruh linier antara variabel Independen Exogenus Pajak, Retribusi dan Belanja Langsung terhaddap variabel Dependen Endogenus Pertumbuhan Ekonomi. Kesimpulan adalah model regresi diatas sudah layak dan benar dengan nilai Sig 0,014..

\section{Menghitung Pengaruh Langsung DE (Direct Effect)}

Pengaruh Variabel Pajak terhadap Belanja Langsung

$$
\mathrm{X} 1 \mathrm{ke} \mathrm{Y} 1=1,970
$$

Pengaruh Variabel Retribusi terhadap Belanja Langsung

$$
\mathrm{X} 2 \mathrm{ke} \mathrm{Y} 1=0,473
$$

Pengaruh Variabel Pajak terhadap Pertumbuhan Ekonomi

$$
\mathrm{X} 1 \mathrm{ke} \mathrm{Y} 2=1.333
$$


Pengaruh Variabel Retribusi terhadap Pertumbuhan Ekonomi

$\mathrm{X} 2 \mathrm{ke} \mathrm{Y} 2=-1.952$

Pengaruh Variabel Belanja Langsung terhadap Pertumbuhan Ekonomi

$\mathrm{Y} 1 \mathrm{ke} \mathrm{Y} 2=2.601$

\section{Pengaruh Tidak Langsung IE (Indirect Effect)}

Pengaruh variabel pajak terhadap Pertumbuhan Ekonomi Melalui Belanja Langsung

$$
\text { PY1X1 x PY2Y1 = }(1.970 \times 2.601)=5.123
$$

Pengaruh variabel Retribusi terhadap Pertumbuhan Ekonomi melalui Belanja Langsung

$$
\mathrm{PY} 1 \mathrm{X} 2 \times \mathrm{PY} 2 \mathrm{Y} 1=(0.473 \times 2.601)=1.230
$$

\section{Pengaruh Total (Total Effect)}

Pengaruh Variabel pajak dan Belanja Langsung terhadap Pertumbuhan Ekonomi

$$
\mathrm{PY} 1 \mathrm{X} 1+\mathrm{PY} 2 \mathrm{Y} 1=1.970+2.601=4.571
$$

Pengaruh Variabel Retribusi dan Belanja langsung tehadap Pertumbuhan Ekonomi.

PY1X2 + PY2Y1 $=0.473+2.601=3.074$

Gambar 4.7 Diagram jalur pengaruh $\mathrm{X} 1$ dan X2 tehadap Y1 dan dampaknya ke Y2

Sub Struktur 1: $\mathrm{Y} 1: \mathrm{Y} 1 \mathrm{X} 1+\mathrm{Y} 1 \mathrm{X} 2+\mathrm{e}_{1}$

Sub Struktur 2: Y2: Y2X1 + Y2X2 + $\mathrm{e}_{2}$

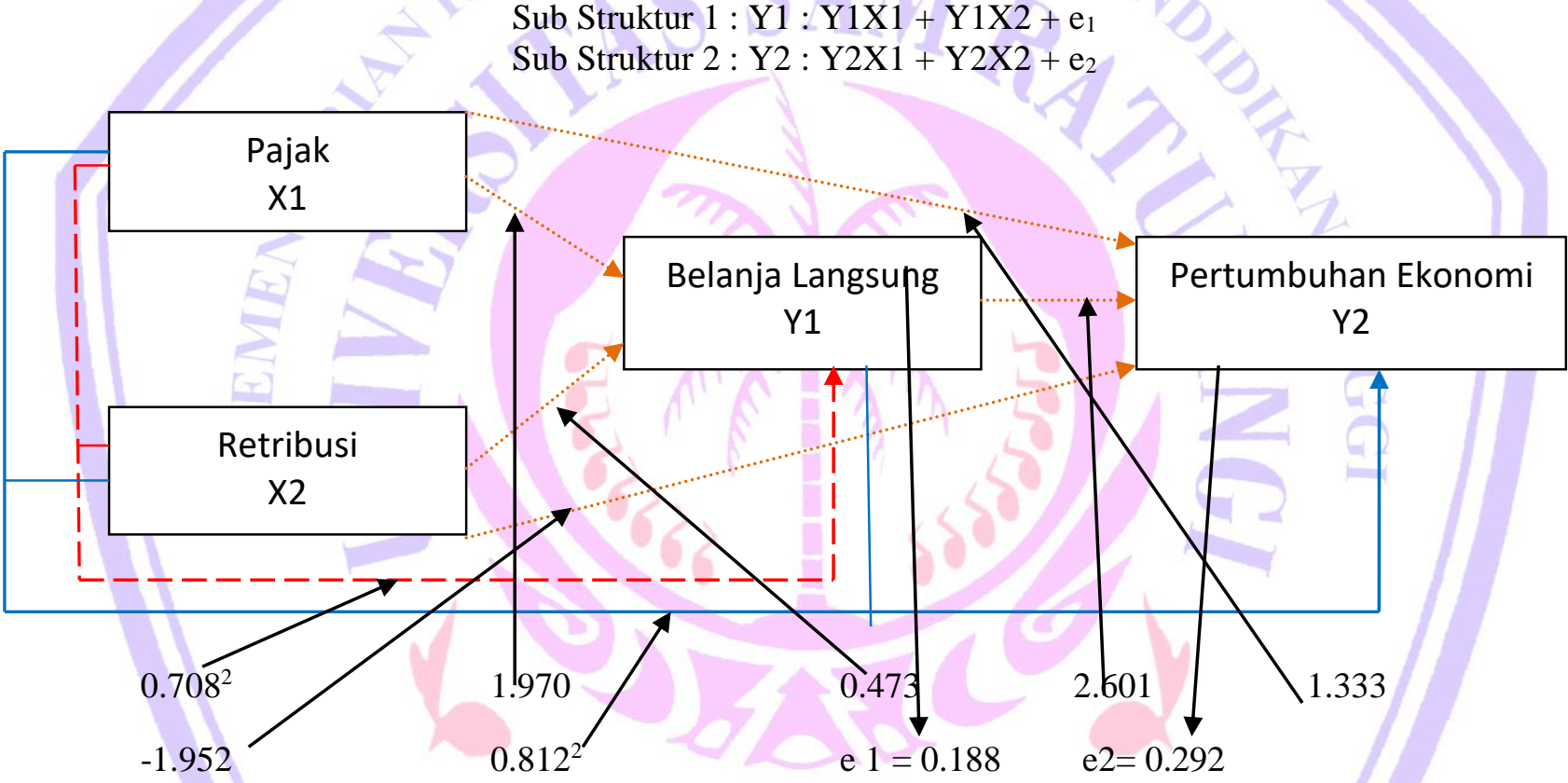

Ket : $\quad$............... Pengaruh Langsung

--- Pengaruh gabungan $\mathrm{X} 1$ dan $\mathrm{X} 2 \mathrm{ke} \mathrm{Y} 1$

Dimana :

$$
\text { - Pengaruh Gabungan X1, X2 dan Y1 ke Y2 }
$$

1. Pengaruh variabel Pajak dan retribusi terhadap belanja langsung adalah sebesar $0.708^{2}$

2. Pengaruh Variabel Pajak terhadap belanja langsung adalah 1.970

3. Pengaruh Variabel retribusi terhadap belanja langsung adalah 0.473

4. Pengaruh Variabel Belanja Langsung terhadap Pertumbuhan Ekonomi adalah sebesar 2.601

5. Pengaruh variable pajak terhadap pertumbuhan ekonomi secara langsung adalah sebesar 1.333

6. Pengaruh variable retribusi terhadap pertumbuhan ekonomi secara langsung adalah sebesar -1.952

7. Pengaruh variable pajak, retribusi dan belanja langsung terhadap pertumbuhan ekonomi adalah sebesar $0.812^{2}$

8. Pengaruh variable pajak terhadap pertumbuhan ekonomi melalui variable belanja langsung adalah sebesar 5.123 
9. Pengaruh variable retribus terhadap pertumbuhan ekonomi melalui variable belanja langsung adalah 1.230

\section{Pembahasan}

Dari hasil penelitian yang dilakukan mendapatkan hasil, tingkat pendapatan pajak tidak memberi pengaruh yang signifikan terhadap alokasi belanja langsung, hal ini mengindikasikan bahwa pendapatan asli daerah (PAD) yang notabene bergantung sebagian besar terhadap pendapatan pajak belum memberi kotribusi yang maksimal karena sejatinya alokasi belanja langsung yang merupakan perwujudan dari belanja investasi yang dilakukan pemerintah untuk meningkatkan kesejahteraan masyarakat semestinya merupakan pengalokasian dari pendapatan pemerintah yang tentunya berasal dari pajak serta retribusi.

Dengan tingkat pengaruh serta signifikansi yang amat kecil tentu juga menjadi gambaran kemandirian daerah dalam hal ini kota Bitung, begitupun halnya dengan tingkatan pendapatan yang berasal dari pajak maupun retribusi daerah yang belum bisa memberi pengaruh yang signifikan terhadap belanja langsung yang dilakukan oleh pemerintah.

Berdasarkan hasil ini dapat menjadi gambaran kemampuan daerah dalam mengelola keuangannya, apakah sudah mampu mengelola secara maksimal anggaran pendapatan dan belanja daerah (APBD) yang dimiliki untuk meningkatkan kemandirian yang tentunya dapat terlihat dari jumlah pendapatan pajak dan retribusi yang dimiliki serta alokasi anggaran yang dianggarkan untuk belanja langsung dimana belanja langsung merupakan jenis belanja yang nantinya akan menjadi investasi pemerintah daerah atau dalam hal ini pemerintah kota Bitung untuk semakin meningkatkan kemandiriannya.

Dengan tingkat kemandirian serta pertumbuhan yang semakin baik maka akan dapat berimbas pada pertumbuhan ekonomi, seperti dalam penelitian yang dilakukan didapatkan hasil bahwa pajak, retribusi serta alokasi belanja langsung memberikan pengaruh yang sangat signifikan terhadap pertumbuhan ekonomi kota Bitung.

\section{KESIMPULAN DAN SARAN}

\section{Kesimpulan}

Pemerintah Kota Bitung dalam hal pendapatan pajak maupun retribusi masih amat kurang dalam membiayai pengeluarannya atau dalam penelitian yang dilakukan adalah alokasi belanja langsung, hal ini menjadi gambaran bagaimana tingkat kemandirian yang dimiliki serta bagaimana tingkat ketergantungan pemerintah kota Bitung terhadap alokasi dana transfer dari pemerintah pusat masih amat tinggi sehingga perkembangan yang terjadi serta pembangunan di kota bitung masih amat kecil.

\section{Saran}

Berdasarkan hasil penelitian pengaruh pajak dan retribusi terhadap belanja langsung atau belanja pembangunan yang dilakukan oleh pemerintah dan pengaruhnya terhadap pertumbuhan ekonomi penulis coba memberikan saran :

a. Mempertahankan kinerja pengelolaan yang sudah tertata dengan baik di pemerintah kota Bitung, terlebih dalam pengelolaan sumber-sumber pendapatan asli daerah yang masih belum terkelola secara maksimal agar dapat memberikan kotribusi yang lebih maksimal terhadap belanja pembangunan.

b. Membuka sector-sektor ekonomi potensial yang dapat menjadi sumber-sumber pendapatan daerah agar dapat meningkatkan taraf kemandiriannya dan tidak terlalu bergantung pada kucuran dana dari pemerintah pusat dalam bentuk dana transfer, dan dengan adanya sumber-sumber ekonomi baru ini diharapkan belanja pembangunan yang dilakukan oleh pemerintah Kota Bitung akan bisa berkembang lebih baik lagi dan tentunya menjadi salah satu sarana bagi pemerintah untuk mengurangi tingkat kemiskinan karena dengan adanya sumber perekonomian yang baru maka tentunya akan menyerap tenaga kerja yang belum bisa terserap sebelumnya karena kurangnya kesempatan kerja.

c. Meningkatkan alokasi belanja langsung sehingga memberi pengaruh positif terhadap pertumbuhan ekonomi yang terjadi di kota Bitung. 


\section{DAFTAR PUSTAKA}

Abdul Halim (2009). Sistem Pengendalian Manajemen. UPP STIM YKPN. Cetakan Ketiga Maret.

Abdul Halim. (2003). Analisis Investasi. Edisi Pertama, Penerbit Salemba Empat : Jakarta

Adi, Priyo Hari, 2006. "Hubungan antara Pertumbuhan Ekonomi Daerah, Belanja Pembangunan dan Pebdapatan Asli Daerah (Studi Kasus pada Kabupaten dan Kota se Jawa-Bali)”. Simposium Nasional Akuntansi 9 Padang.

Abdul Hasyim Batubara. 2010. Analisis Rasio Likuiditas dan Profitabilitas Pada PT. Bumi Flora.Unpab Medan

Brotodihardjo, R,Santoso,1995, Pengantar Ilmu Hukum Pajak, Eresco,Bandung

Chen, R. Carl dan Steiner, T. 1999. "Managerial Ownership and Agency Conflicts: A Nonlinear Simultaneous Equation Analysis of Managerial Ownership, Risk Taking, Debt Policy, and Dividend Policy", Financial Review, Vol.34

David, Garson, 2003. Path Analysis. North Carolina State University.

Halim, Abdul dan Mujib, Ibnu, 2009, Problem desentralisasi dan perimbangan keuangan pemerintahan pusat-daerah peluang dan tantangan dalam pengelolaan sumber daya daerah, Tesis Sekolah Pascasarjanan UGM, Yogyakarta.

Jonathan Sarwono, 2006, Metode Penelitian Kuantitatif \& Kualitatif, (Yogyakarta; Graha Ilmu, Maimunah, Mutiara. 2006. "Flypaper Effect pada Dana Alokasi Umum (DAU) dan Pendapatan Asli Daerah (PAD) Terhadap Belanja Daerah Studi Kasus Kabupaten/Kota di Pulau Sumatera“. Simposium Nasional Akuntansi XI. Padang.

Mardiasmo. 2002. Akuntansi Sektor Publik. Penerbit Andi. Yogyakarta.

Mardiasmo. 2004. Akuntansi Sektor Publik. Penerbit Andi. Yogyakarta.

Mahmudi (2010), Manajemen Kinerja Sektor Publik, Edisi Kedua, UPP STIM YKPN, Yogyakarta.

Mahmudi, 2009. Manajemen Keuangan Daerah. Yogyakarta

Rutherford, Robert D dan Minja Kim Choe. (1993). Statistical Model For Causal Analysis. New York:John Wiley \& Sons.Inc.

Sirojuzilam dan Mahalli, K. 2010. Regional. Pembangunan, Perencanaan dan Ekonomi. USU Press. Medan.

Sirojuzilam. 2005. Regional Planning and Development. Wahana Hijau. Jurnal Perencanaan dan Pengembangan Wilayah. Vol.1 Nomor 1 Agustus 2005.

Susanto A.B, Ghifari A.B, Susanto A, Suradinata E, Wijanarko H, Supranto J, Karmaji, Oyong R, Nurbaya S dan Martha S, 2010, Reinvensi pembangunan ekonomi daerah, Esensi Erlangga Group, Jakarta. Mardiasmo (1992), Perpajakan, Edisi 2, Yogyakarta : Penerbit Andi Offset

Sumitro, Rochmad. 1979. Dasar-dasar Hukum Pajak dan PajakPendapatan 1944, cet. IX, Jakarta : Eresco

Sadono Sukirno, 2006, Ekonomi Pembangunan Proses masalah dan Dasar Kebijakan, cetakan ketiga, Penerbit Kencana, Jakarta.

Sirojuzilam. 2011.Teori Lokasi. Medan: USU Press.

Soetiono, Dedi NS. 2011. Ekonomi Pengembangan Wilayah Teori dan Analisis. Lembaga Penerbit FEUI : Jakarta

Singgih Santoso, 2002 Mengolah Data Statistik Secara Professional, Elex Media Komputindo, Jakarta.

Saggaf Said, 1999 Analisa Pengaruh Pendapatan Asli Daerah Terhadap Peningkatan Pertumbuhan Ekonomi di Kotamadya Dati II Pekanbaru, Tesis Program Pascasarjana USU Medan

Sembiring, H. 2001. Komoditas Unggulan Pertanian Propinsi Sumatera Utara. Sumatera Utara : Badan Penelitian dan Pengembangan Teknologi.

Sarwono, Jonathan. (2007). Analisis Jalur untuk Riset Bisnis dengan SPSS. Yogyakarta: Penerbit ANDI.

Todaro, MP.2000. Economic Development seventh edition, Longman Inc.England.

Warsito Kawedar, Abdul Rohman, Sri Handayani. 2008. Akuntansi Sektor Publik Pendekatan Penganggaran Daerah dan Akuntansi Keuangan Daerah. Badan Penerbit Universitas Diponegoro, Semarang. 
Undang-Undang No.32 Tahun 2004 Tentang Pemerintahan Daerah (Lembaran Negara Republik Indonesia Tahun 2004 Nomor 125)

---Undang-Undang No.33 tahun 2004 Tentang Perimbangan Keuangan Antara Pemerintah Pusat

Dan Pemerintah Daerah. ( Lembaran Negara Republik Indonesia Tahun 2004 Nomor 126)

------------Undang-Undang Republik Indonesia, Nomor 28 Tahun 2007 Tentang Ketentuan Umum Dan

Tata Cara Perpajakan.

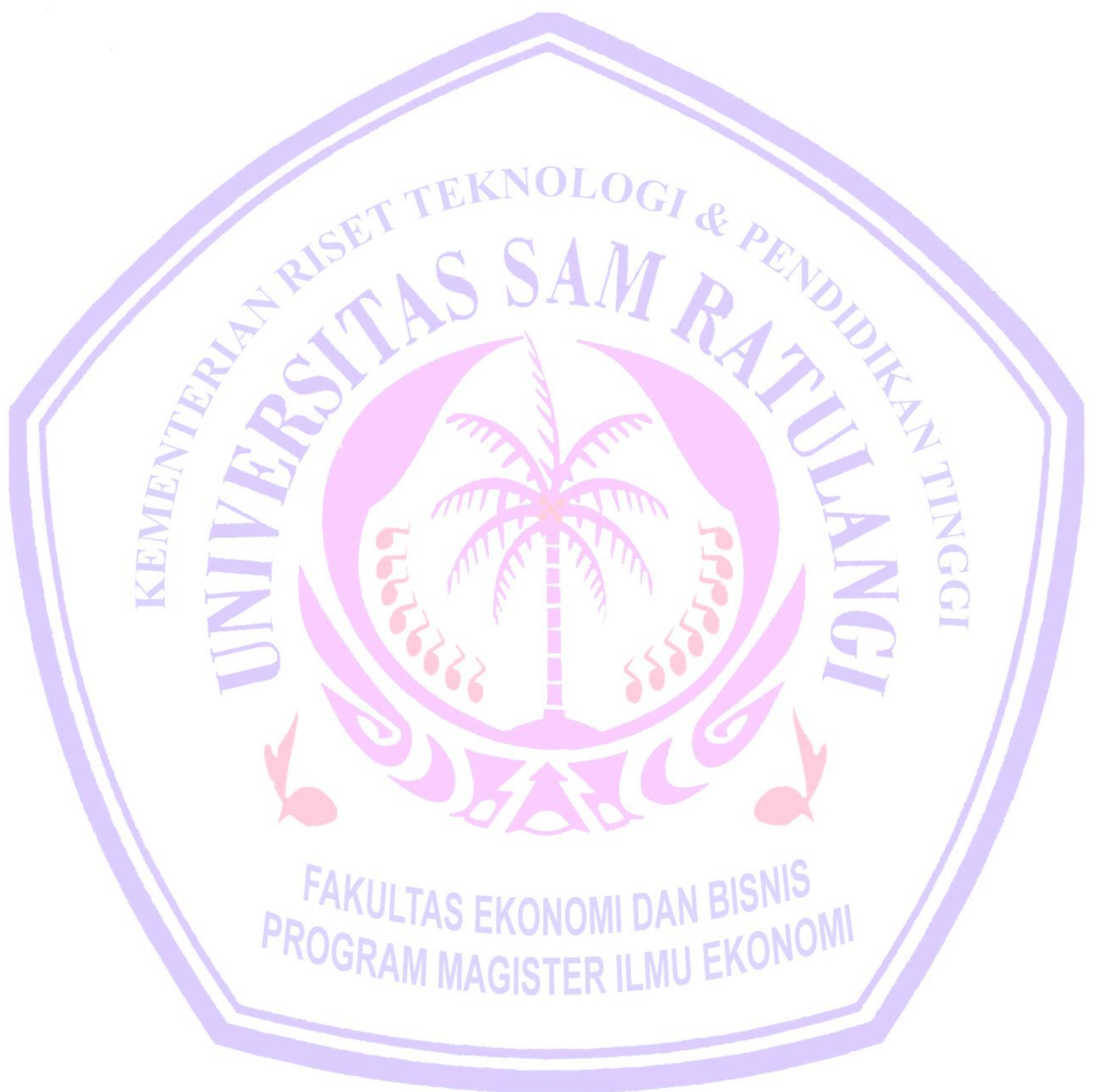

